\title{
Sistem Inspeksi Label Produk Menggunakan Metode Golden Template Comparison dan Konveyor Pemilah
}

\author{
Fitriyanti Nakul $^{*}$, Rudi Pardede ${ }^{1}$, B. Budiana ${ }^{1}$, Rahmi Mahdaliza ${ }^{1}$, Heru Wijanarko $^{1}$ \\ ${ }^{1}$ Politeknik Negeri Batam, Batam, Indonesia \\ *Email: fitriyantinakul@polibatam.ac.id
}

\begin{abstract}
Inspeksi label produk menjadi bagian penting dalam pengawasan dan kendali kualitas hasil produksi di industri. Beberapa industri masih menerapkan pemeriksaan label produk secara visual-manual oleh operator. Cara ini memiliki keterbatasan dan cenderung tidak cukup efektif. Penelitian ini mengembangkan sistem inspeksi kualitas pelabelan produk secara otomatis menggunakan penggabungan metode golden template comparison (GTC) dan konveyor pemilah. Sistem dibuat untuk mendeteksi cacat pada dua sisi label di satu produk yang sama. Desain konveyor pemilah mampu memindahkan produk ke proses deteksi dua sisi label dan memilah produk secara otomatis untuk ditempatkan pada wadah yang disediakan berdasarkan hasil inspeksi produk. Penggunaan golden template comparison berdasarkan analisis pixel matching ini efektif membandingkan intensitas pixel dari objek yang diperiksa dengan golden template yang sudah ditentukan. Hasil penelitian menunjukkan sistem ini berhasil menganalisa produk pass dan fail berdasarkan perhitungan total defect area kedua sisi front dan back pada label produk sesuai standar acuan klasifikasi cacat dengan \% RSD mencapai 3,5\%, yang berarti sistem kerja alat memiliki tingkat ketelitian tinggi.
\end{abstract}

Kata kunci: label produk, defect, golden template comparison, konveyor

\section{PENDAHULUAN}

DALAM industri manufaktur dan fabrikasi, produk yang diproduksi umumya diberi kemasan dan label sebagai identitas dan ciri khas produk agar mudah dikenal oleh konsumen. Setiap label atau merek produk pada satu jenis produk akan memiliki deskripsi dan bentuk yang sama sesuai standar yang ditentukan industri. Untuk memastikan kualitas produk, sebagian besar industri menerapkan proses Quality Control (QC) yang masih dilakukan secara visual-manual dengan mengandalkan penglihatan dan ketelitian kerja para operator QC. Cara ini tentu memiliki keterbatasan karena faktor kelelahan atau ketidaktelitian dapat menyebabkan inspeksi produk tidak efektif dan efisien dalam pelaksanaannya.

Proses QC dalam memeriksa cacat atau kerusakan pada label produk dapat dimaksimalkan dengan menerapkan bantuan teknologi terkini. Beberapa studi dan penelitian yang pernah dilakukan untuk mengatasi masalah terkait deteksi objek diantaranya memanfaatkan teknologi pengolahan citra, Automated Visual Inspection System (AVIS) dan teknologi pendukung lain yang dipadukan dalam pengembangannya [1-3]. Salah satu studi pendeteksian cacat produk menggunakan filter warna HSL dan template matching mampu mengklasifikasikan produk kaleng berdasarkan kategori kaleng OK (Good) atau reject [4]. Dalam studi ini, sistem dapat menginspeksi objek hanya di satu sisi yakni sisi bagian atas kaleng. Selain itu, belum ada kriteria klasifikasi lain seperti pixel matching yang dibuat dalam pendeteksian objek yang mengalami sedikit reject sehingga sulit untuk dikategorikan. Sementara itu, studi desain AVIS untuk mendeteksi tingkat pelabelan dan tingkat cairan yang tidak tepat pada botol minuman berhasil disimulasikan menggunakan algoritma image processing dan diadakan simulasi menggunakan prototype konveyor belt [3]. Konveyor yang dibuat pada penelitian ini berfungsi sebatas untuk menirukan konveyor belt yang beroperasi di pabrik botol minuman tanpa desain khusus untuk mendukung hasil capture gambar dari produk botol minuman yang diinspeksi.

Mengatasi keterbatasan dari metode yang telah digunakan pada penelitian sebelumnya, maka penelitian ini mengusulkan sistem inspeksi cacat label produk secara otomatis menggunakan metode golden template comparison (GTC) yang terintegrasi dengan konveyor pemilah tanpa bantuan operator. Sistem ini dibuat untuk mendeteksi cacat pada dua sisi label di satu produk yang sama, yakni bagian depan dan belakang, dan mampu bekerja otomatis memilah produk kategori pass atau fail berdasarkan hasil deteksi untuk. ditempatkan pada masing-masing wadah yang disediakan. Prinsip kerja sistem ini didukung dengan bantuan input data berupa gambar label produk yang ditangkap oleh kamera. Selanjutnya, pemrosesan citra dilakukan otomatis dan konveyor pemilah akan aktif. Jika terdeteksi adanya cacat pada label, maka produk akan otomatis dipisah ke wadah yang telah disediakan. Pada desain kerangka mekanik sistem konveyor dibuat menggunakan tambahan perangkat gripper untuk memutar posisi label dalam mendeteksi cacat pada dua sisi label produk dan memilah produk pass atau fail sesuai hasil 
deteksi total defect area pada sisi masing-masing pelabelan. Metode GTC dengan teknik analisis intensitas pixel matching dipilih karena sederhana secara teknis penggunaan mampu untuk mengklasifikasi label produk dengan kategori pass (OK) dan fail (cacat). Selain itu metode ini juga memiliki waktu pemrosesan yang relatif cepat dengan tingkat akurasi yang tinggi[4]. Dengan mengintegrasikan metode golden template comparison dan konveyor pemilah maka sistem kerja alat diharapkan dapat lebih maksimal dan lebih baik.

Penelitian ini dapat menjadi alternatif yang dimanfaatkan khususnya pada industri-industri skala besar, terutama sebagai alat bantu untuk memudahkan pekerjaan operator QC. Selain itu, perbaikan dan pengembangan baik dari segi waktu, tenaga, dan biaya produksi dapat dievaluasi untuk menghasilkan kualitas maksimal sehingga efektivitas dan efisiensi proses produksi dapat ditingkatkan.

\section{METODE}

Perancangan sistem inspeksi label produk menggunakan pendekatan metode golden template comparison dan konveyor pemilah terdiri dari rancangan perangkat keras dan perangkat lunak.

\section{A. Perancangan Perangkat Keras}

Komponen yang digunakan pada perancangan perangkat keras terdiri dari modul mikrokontroller Arduino uno sebagai sarana prosesor yang mendukung sistem kerja alat. Sensor infrared dan switch pada bagian input, dan pada bagian output terdiri dari relay, motor servo, motor DC, motor stepper, driver, dan micro-USB (Gambar 1).

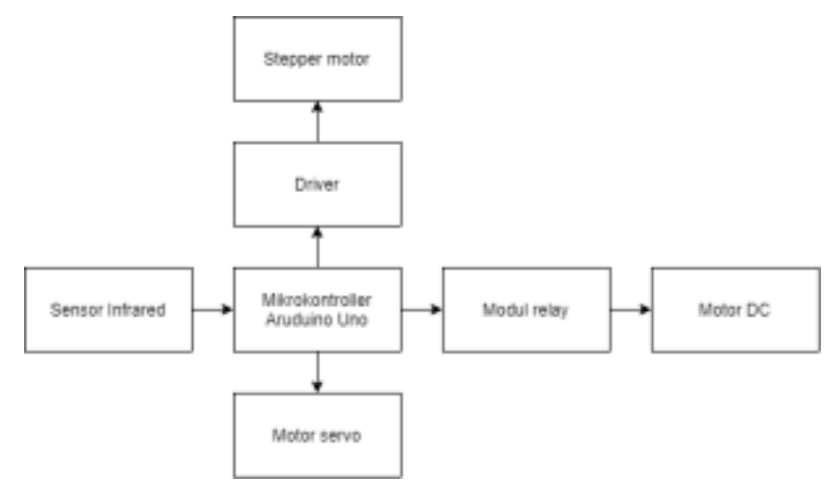

Gambar 1. Perancangan perangkat keras pada sistem inspeksi label produk.

Motor stepper dan motor servo berfungsi sebagai perangkat gripper untuk menjepit dan memutar arah $90^{\circ}$ pada produk. Sedangkan satu motor servo lainnya difungsikan sebagai pemilah produk yang dideteksi fail. Motor DC pada rangkaian menggunakan daya sebesar $9 \mathrm{~V}$ berfungsi untuk menggerakkan belt pada konveyor. Pengontrolan motor DC tersebut menggunakan perangkat modul relay yang berfungsi sebagai saklar. Selanjutnya, sensor infrared berperan sebagai pendeteksi untuk mengetahui adanya produk yang melewatinya.

Desain mekanik sistem (Gambar 2) dibuat menggunakan konveyor. Konveyor dilengkapi dengan gripper dan pemilah untuk memutar produk dan memilah produk yang teridentifikasi dalam kategori pass dan fail pada tempat atau wadah yang disediakan.

\section{B. Perancangan Perangkat Lunak}

Perancangan pada perangkat lunak menggunakan vision builder terdiri dari beberapa proses utama yakni; (i) pengambilan citra gambar pada label sisi depan dan belakang menggunakan kamera, citra yang tertangkap kamera dikonversi ke dalam bentuk grayscale menggunakan vision assistant; (ii) gambar akan diinspeksi menggunakan match pattern dan detect defects untuk mengetahui adanya kecocokan atau defect pada gambar; Selanjutnya, (iii) membuat template baru match pattern dan detect defects terlebih dahulu untuk dicocokan dengan gambar yang diinspeksi.

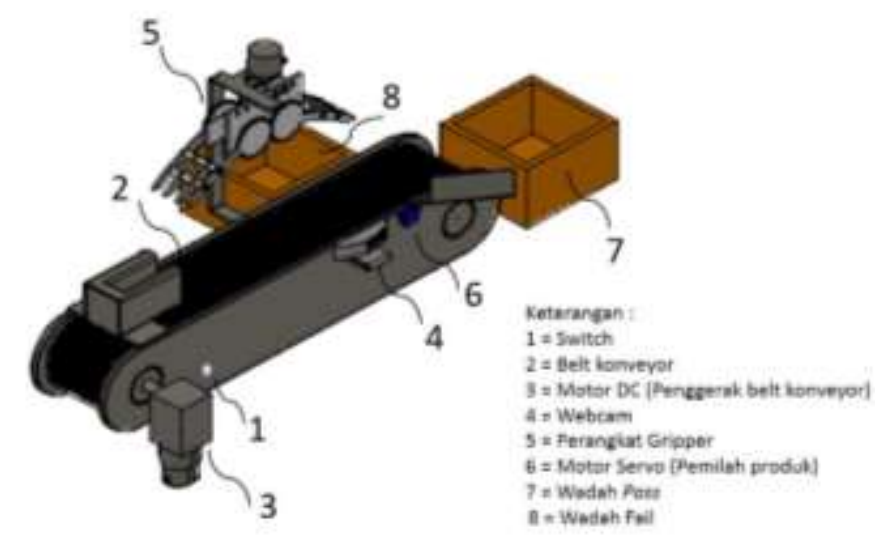

Gambar 2. Desain mekanik sistem inspeksi label produk.

Dilakukan tahapan proses inspeksi sesuai urutan yang meliputi;

1) Color plane extraction

Gambar diekstrak menjadi HSL-Luminance Plane yang berfungsi untuk mengatur nilai kebercahayaan atau lightness dengan minimum 0 dan maksimum 240. Nilai tengahnya adalah 120 sesuai dengan warna aslinya.

2) Match Pattern

Teknik pencocokan pola dengan membuat template yang mewakili objek yang diinpeksi. Langkah inspeksi ini akan menghitung skor kecocokan pola gambar yang diinspeksi dengan template. Pemlilihan gambar template yang baik mempunyai peran penting untuk mendapatkan hasil yang baik. Jadi ada beberapa faktor untuk membuat gambar template yang baik yaitu simetri, detail fitur, informasi pada posisi, dan informasi latar belakang.

3) Detect Defects

Menggunakan teknik golden template comparison, yaitu membandingkan instensitas pixels suatu gambar yang diinspeksi dengan golden template yang dibuat. Sampel produk diklasifikasikan menjadi dua kategori yakni kategori pass dan fail. Tampilan interface dirancang dalam NI vision builder[5].

\section{Golden Template Comparison}

Golden template comparison (GTC) merupakan metode yang dapat digunakan untuk mendeteksi cacat pada gambar 
dalam 2D (dua dimensi)[6]. Dengan analisis pixel matching dilakukan perbandingan intensitas pixel gambar yang sedang diperiksa dengan golden template. Golden template adalah gambar yang memuat representasi ideal dari suatu objek yang sedang diinspeksi. Pixel dalam gambar inspeksi ditandai sebagai cacat jika intensitasnya tidak cocok dengan pixel yang sesuai dalam golden template dalam toleransi yang ditentukan.

Konsep kerja inspeksi visual menggunakan metode GTC merujuk pada konsep Ni Vision. Secara teknis, dilakukan pengurangan intensitas pixel dari bagian gambar ideal dengan bagian gambar yang diinspeksi. Setiap cacat yang terlihat pada bagian yang diinspeksi akan muncul sebagai perbedaan intensitas pada gambar cacat yang dihasilkan[7]. Ilustrasi konsep kerja dari metode ini ditunjukkan pada Gambar 3.

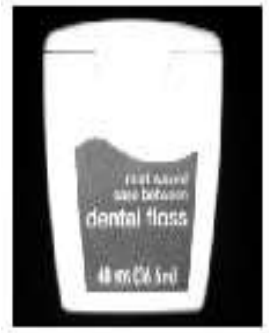

8.

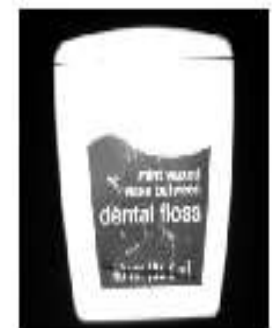

b.

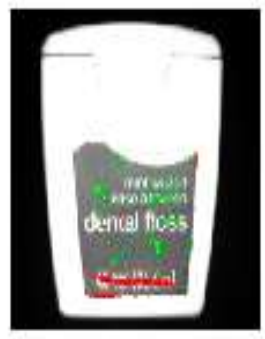

c.
Gambar 3. Ilustrasi konsep golden template comparison (GTC). [6]

Gambar 3 menunjukkan (a) golden template pada aplikasi inspeksi label; (b) menunjukkan gambar yang diinspeksi; (c) gambar cacat yang dihasilkan. Area yang cacat terdeteksi ketika gambar yang diinspeksi lebih terang dari template, dilapisi dengan warna hijau. dan area yang cacat dengan gambar yang lebih gelap daripada template, dilapisi dengan warna merah.

\section{Prinsip Kerja Sistem Inspeksi Label Produk}

Rancangan program untuk sistem kerja alat (Gambar 4) dimulai saat tombol power aktif sehingga konveyor akan bergerak. Produk akan diletakkan di atas konveyor. Apabila produk tersebut bergerak dan pergerakannya terdeteksi sensor Infrared maka secara otomatis konveyor akan berhenti. Saat kondisi ini pengambilan citra dilakukan pada label sisi depan, setelah label tersebut tertangkap kamera maka pengolahan citra dengan metode GTC akan melakukan proses membandingkan intensitas pixel suatu gambar dengan golden template untuk mengetahui kualitas gambar tersebut memiliki cacat atau tidak. Jika gambar tersebut memiliki total defect area melebihi standar klasifikasi yang ditentukan 130 pixels (Tabel 1), maka produk tersebut dinyatakan fail dan servo akan aktif 45 derajat. Tetapi jika label produk tersebut memiliki total defect area kurang dari 130 pixels, maka servo tidak akan aktif dan gripper akan secara otomatis memutar produk dan mendeteksi kembali label pada sisi belakang. Dengan siklus yang sama seperti sebelumnya, jika total defect area melebihi 130 pixels maka motor servo akan bergerak 45 derajat, sedangkan jika total defect area kurang dari 130 pixels, maka motor servo tidak akan aktif dan konveyor otomatis bergerak. Siklus kerja dari sistem ini akan berkelanjutan hingga sistem di off kan.

\section{E. Teknik Pengujian}

Objek yang digunakan dalam penelitian ini berupa label pada produk antiseptik (Gambar 5). Label terdiri dari kombinasi gambar dan kata-kata yang berfungsi sebagai informasi produk. Label produk memuat informasi berupa nama produk, komposisi, tanggal kedaluwarsa, dan isi produk. Label produk diinspeksi pada kedua sisi yakni sisi depan (front) dan sisi belakang (back).

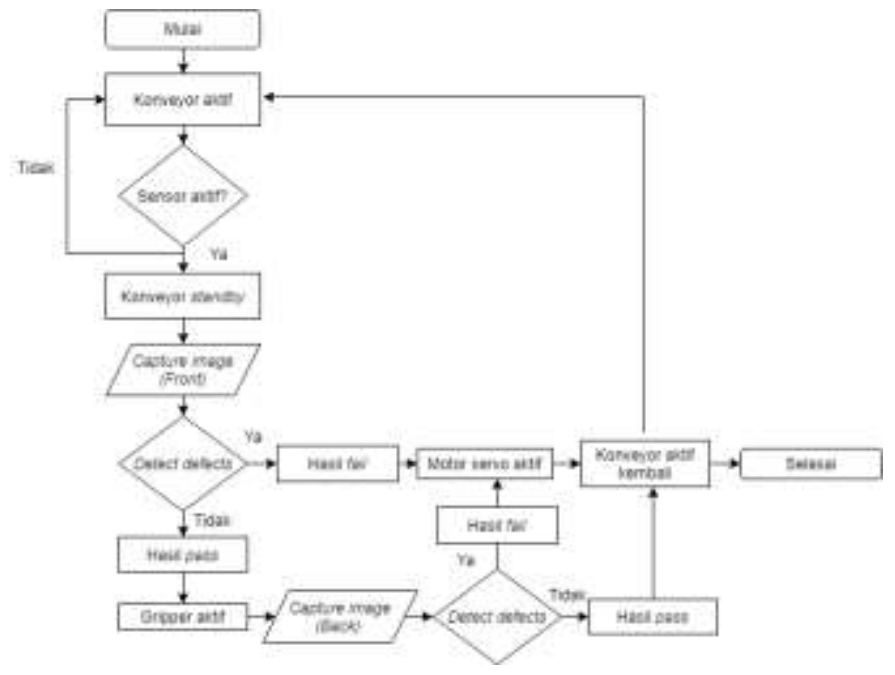

Gambar 4. Flowchart program kerja sistem inspeksi label produk.

Peneliti melakukan pengujian terhadap 7 sampel dengan 5 kali pengulangan pengambilan data untuk menentukan tingkat ketelitian dari sistem yang dirancang. Merk dari label produk dipilih acak tanpa ada maksud tertentu dan tidak ada kepentingan lain selain digunakan sebagai tujuan riset.

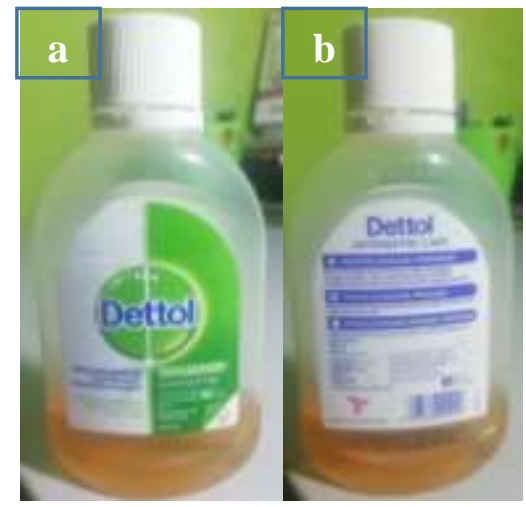

Gambar 5. Objek penelitian (a) label produk sisi depan; (b) label produk sisi belakang.

Merujuk standar AQL (Acceptabel Quality Level) yang digunakan di industri umumnya memiliki 3 klasifikasi defect yaitu minor, major, dan critical[8]. Sistem ini hanya menggunakan 2 klasifikasi, yaitu minor dan major untuk mendeteksi defect pada label produk. Selanjutnya, klasifikasi cacat label produk berdasarkan besar total defect area ditunjukkan pada Tabel I. 
TABEL I

DAFTAR STANDAR KLASIFIKASI CACAT

\begin{tabular}{cccc}
\hline \hline $\begin{array}{c}\text { Defect } \\
\text { Classification }\end{array}$ & $\begin{array}{c}\text { Total Defect area } \\
\text { (pixels) }\end{array}$ & $\begin{array}{c}\text { Largest Defect } \\
\text { area (pixels) }\end{array}$ & Status \\
\hline Minor & $\leq 130$ & - & Pass \\
Major & $>130$ & - & Fail \\
\hline
\end{tabular}

Nilai 130 pixels diperoleh dari beberapa hasil uji coba berdasarkan pertimbangan visual pada defect yang dapat menganggu tampilan label dan keterbatasan performa kamera dalam mendeteksi defect. Partikel hasil tangkap kamera dapat mempengaruhi hasil inspeksi sehingga sistem membutuhkan filter untuk menghilangkan partikel-partikel yang tidak berasal dari label. Hasil sebelum dan sesudah dilakukan filter pada sampel yang OK tertampilkan pada Gambar 6.

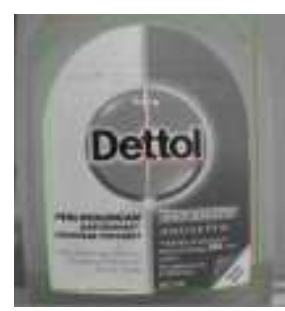

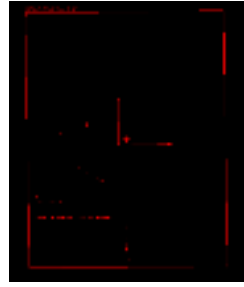

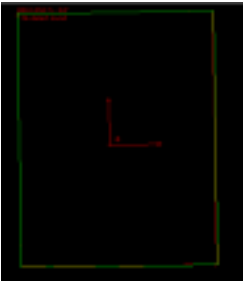

Gambar 6. Hasil deteksi sebelum dan sesudah dilakukan filter (a) hasil deteksi defect pada real capture. (b) hasil deteksi defect tanpa menggunakan filter dalam tampilan overlay, dan (c) menunjukkan hasil deteksi defect menggunakan filter area dalam tampilan overlay.

Pada Gambar 6 (b) tampak adanya partikel-partikel yang tak diinginkan terdeteksi oleh sistem. Setelah menggunakan filter area, partikel-partikel yang tak diinginkan tersebut hilang dan hasil deteksi adalah no defect found atau tidak ditemukan cacat (Gambar 6c). Selanjutnya, penentuan nilai total defect area yang sesuai dengan kamera yang digunakan yaitu webcam nemesis dilakukan melalui beberapa uji coba agar memperoleh range filter yang tepat. Dilakukan uji coba dalam 5 kali pengulangan untuk mendapatkan rata-rata luas partikel pada objek. Hasil pengujian disajukan pada Tabel II.

TABEL II

LUAS PARTIKEL PADA OBJEK

\begin{tabular}{cc}
\hline \hline $\begin{array}{c}\text { Pengujian } \\
\text { ke- }\end{array}$ & $\begin{array}{c}\text { Luas Partikel } \\
\text { (pixels) }\end{array}$ \\
\hline 1 & 125 \\
2 & 127 \\
3 & 124 \\
4 & 116 \\
5 & 124 \\
Nilai rata-rata & 123,2 \\
\hline \hline
\end{tabular}

Dengan perolehan rata-rata luas partikel, maka peneliti memilih range filter melalui perhitungan 5\% dari nilai rata-rata dijumlahkan dengan nilai rata-rata sehingga diperoleh hasil pembulatan sebesar 130 pixels. Jadi range filter yang digunakan pada sistem ini adalah minimum 0 pixels dan maksimum 130 pixels. Untuk memastikan range filter tersebut berhasil, telah dilakukan beberapa iterasi pengujian terhadap 4 sampel dengan luas defect yang berbeda-beda.

\section{HASIL DAN PEMBAHASAN}

Tampilan interface aplikasi berhasil dibuat menggunakan NI Labview Vision builder (Gambar 7) dengan memuat bagian-bagian berupa;

A) 2 Picture Box, untuk menampilan gambar label bagian depan dan belakang.

B) Tab Control, untuk menampilkan hasil temuan berupa angka apabila ada defect di label depan atau belakang.

1. Number of defects : jumlah defect yang ditemukan.

2. Largest defect area : jumlah pixel yang hanya terdapat pada area defect terbesar.

3. Total defect area : jumlah pixel pada semua area defect.

4. Percent defect : persentase gambar yang mengandung defect.

C) Numeric Indicator, tampilan untuk jumlah unit yang sudah diinspeksi dengan status pass maupun fail, serta persentase unit yang pass.

D) Boolean Indicator, berfungsi sebagai indikator dari tahap-tahap inspeksi. Indikator akan hidup atau berwarna hijau jika status dari tahap inspeksi adalah pass. Sebaliknya jika indikator tidak hidup, maka status untuk tahap tersebut adalah fail.

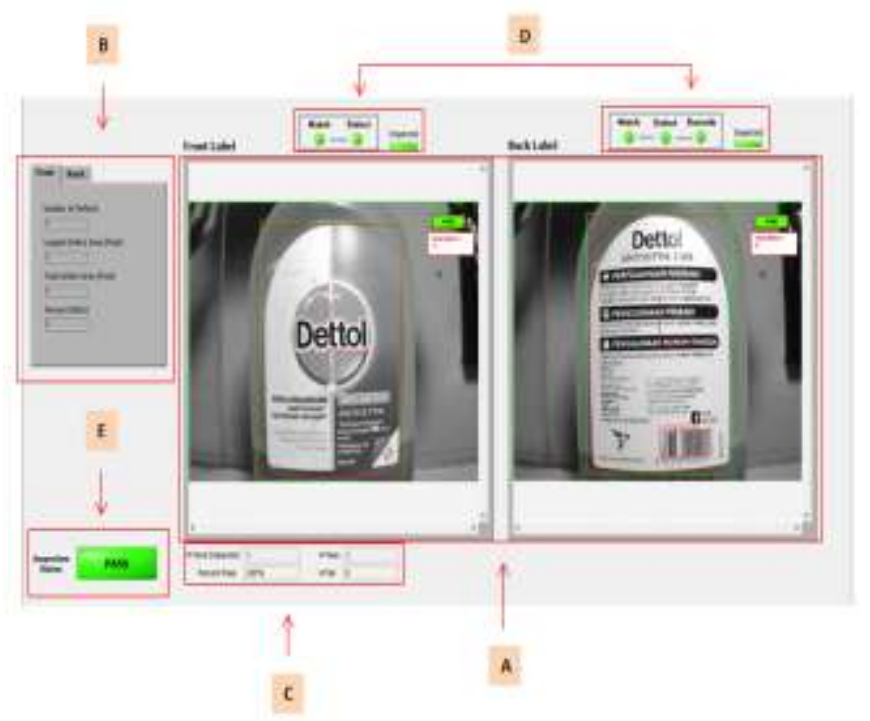

Gambar 7. Tampilan interface aplikasi sistem inspeksi label produk.

Dalam penelitian ini untuk mengetahui inspeksi defect berdasarkan hasil uji sampel label produk, maka hal pertama yang dilakukan adalah dengan cara membandingkan template matching dengan hasil deteksi pada sampel dan memperhatikan jumlah defect (besar defect dinyatakan dalam pixels atau pix^2) untuk mengecek pass atau fail objek tersebut. Template yang dibuat terlebih dahulu di proses match pattern dengan minimum skor yaitu 800. Jadi nilai skor di bawah 800 dikategorikan tidak match dan otomatis akan fail. Kemudian dilanjutkan dengan proses pendeteksian cacat pada label produk mengacu pada standar klasifikasi cacat (Tabel I). Klasifikasi defect minor memiliki status pass, sedangkan major memiliki status fail atau tidak lolos inspeksi. 


\section{A. Pengujian Kategori Sampel Pass}

Berdasarkan data hasil pengujian dari 3 sampel produk pass (Gambar 8) dengan 2 area label yaitu front dan back diperoleh nilai match score dan total defect area dalam pixels dari real capture. Nilai match score pada ketiga sampel tersebut tercatat di atas 800 , sehingga sampel tersebut dikategorikan pass dan secara otomatis dilanjutkan dengan proses detect defects. Total defect area pada proses detect defects diperoleh dari penjumlahan semua defect area yang terdeteksi. Label pada sampel produk No. 1 dan No. 2 tidak terdeteksi atau ditemukan defect ditunjukkan dengan angka 0 pixel, yang berarti produk dikategorikan pass. Berbeda pada bagian back atau label bagian belakang sampel No. 3 terdapat defect dengan nilai defect area yaitu 125 pixels, tetapi dengan klasifikasi cacat minor yakni maksimal total defect area adalah 130 pixels, maka label pada sampel masih dikategorikan pass.

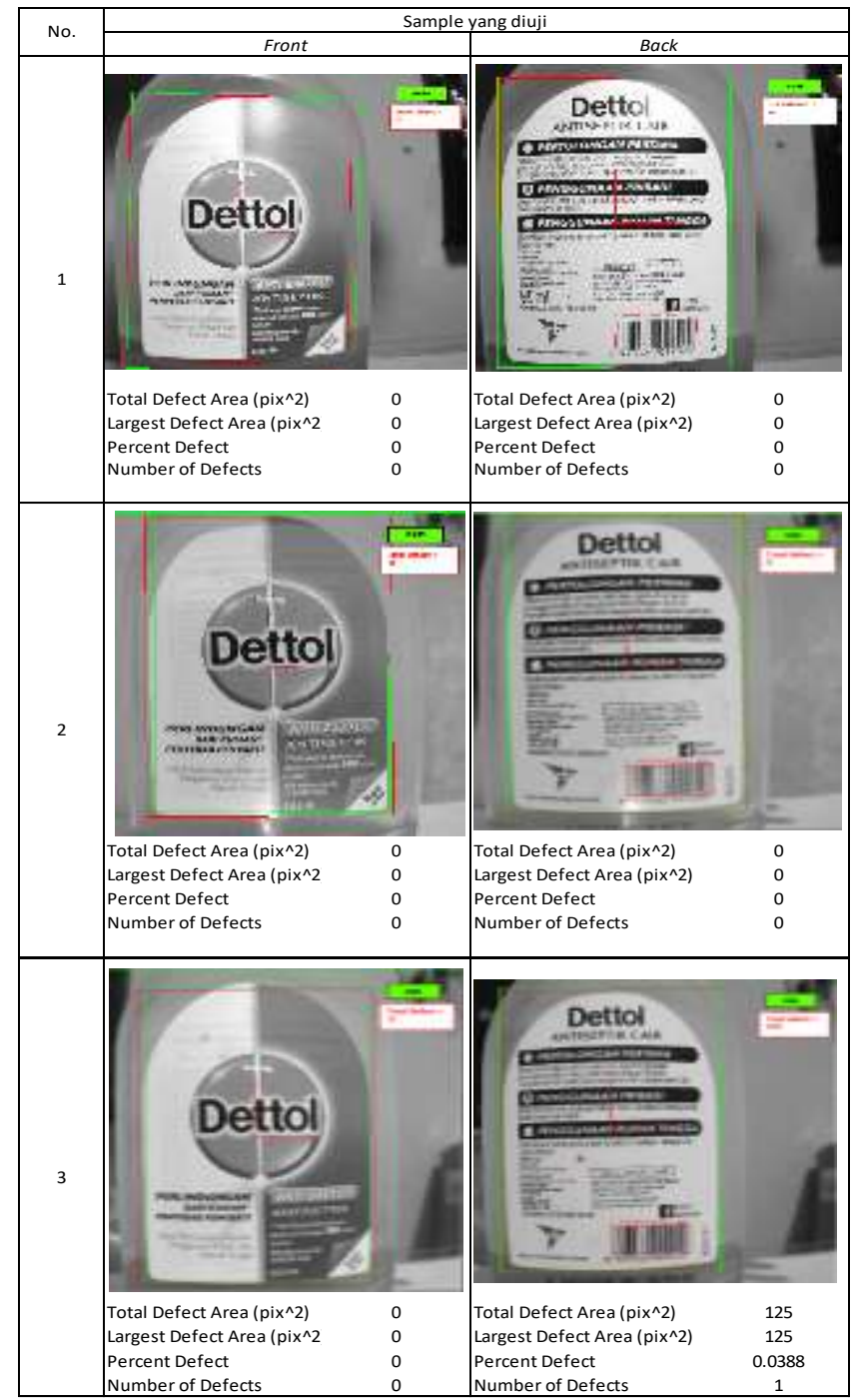

Gambar 8. Hasil pengujian pada kategori sample pass.

Jumlah persen pada label produk dihitung menggunakan formula 1. Dengan jumlah pixel keseluruhan diperoleh dari perkalian dimensi pixel dari sebuah template yaitu 479x671 = 321409 pixels. $\frac{\text { Total Defect Area }}{\text { Jumlah Pixel Keseluruhan }} \times 100 \%$

\section{B. Pengujian Kategori Sampel Fail}

Hasil pengujian pada kategori sample fail (Gambar 9) teramati untuk 4 sampel produk fail dengan 2 area label yaitu front dan back, sehingga terdapat hasil score image dan total defect area dari real capture. Sama seperti pengujian sebelumnya, gambar label pada sampel memiliki match score di atas 800 , sehingga secara otomatis dilanjutkan dengan proses detect defects.

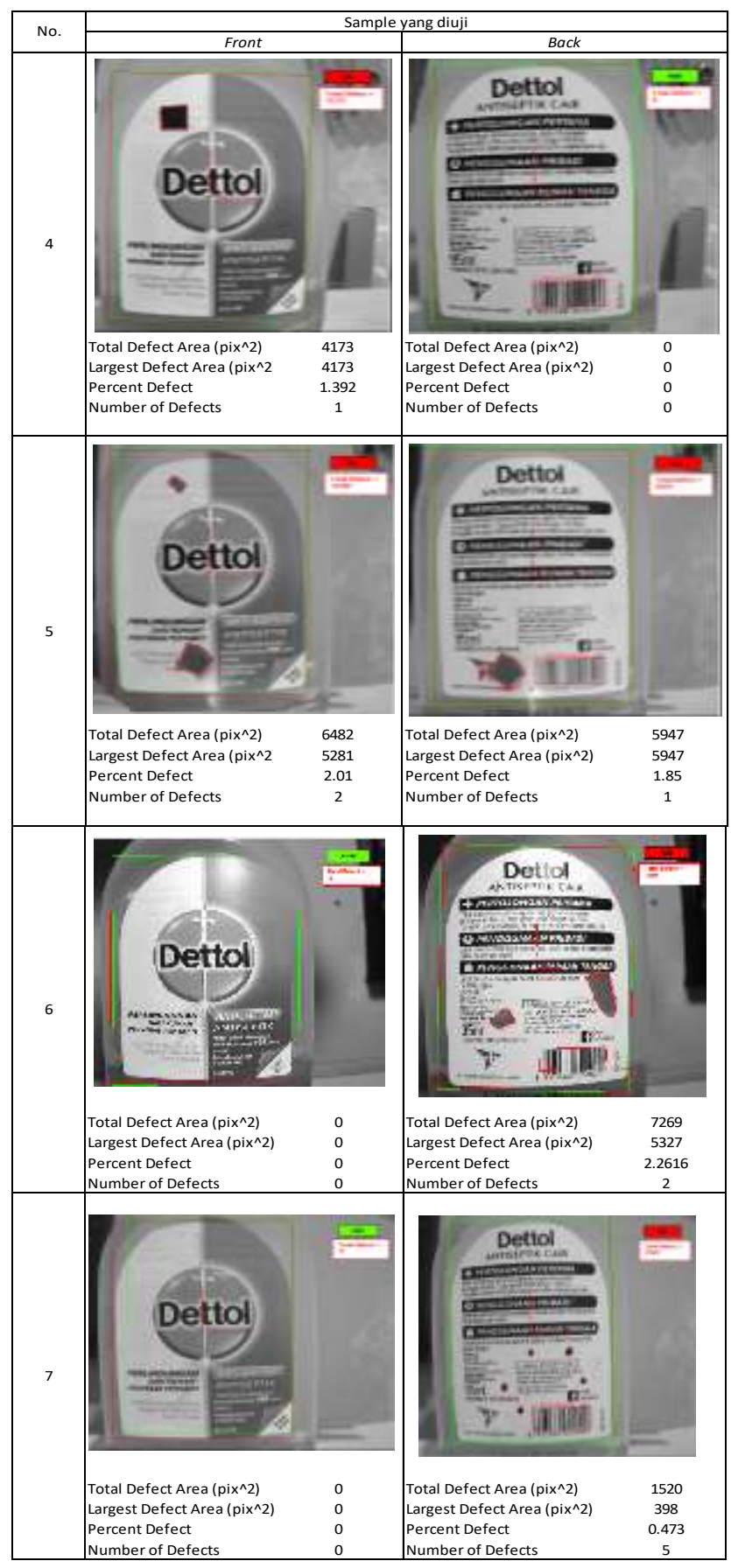

Gambar 9. Hasil pengujian pada kategori sample fail. 
Proses detect defects dari keempat sampel memiliki besar dan jumlah defect yang berbeda-beda. Defect area dapat dilihat pada objek yang dikelilingi garis merah. Konsep dari penentuan status pada produk yang diinspeksi adalah sebuah produk akan dikategorikan pass atau lolos inpeksi jika kedua area label produk berstatus pass. Dengan demikian, jika hanya satu area label saja yang fail, maka status produk tetap dikategorikan fail. Jumlah total defect area pada keempat sampel tersebut adalah lebih dari 130 pixels, sehingga sampel-sampel produk tersebut masuk klasifikasi major yang berarti label tidak lolos inspeksi atau fail. Grafik dari hasil total defect area pada pengujian sampel produk dapat dilihat pada Gambar 10.

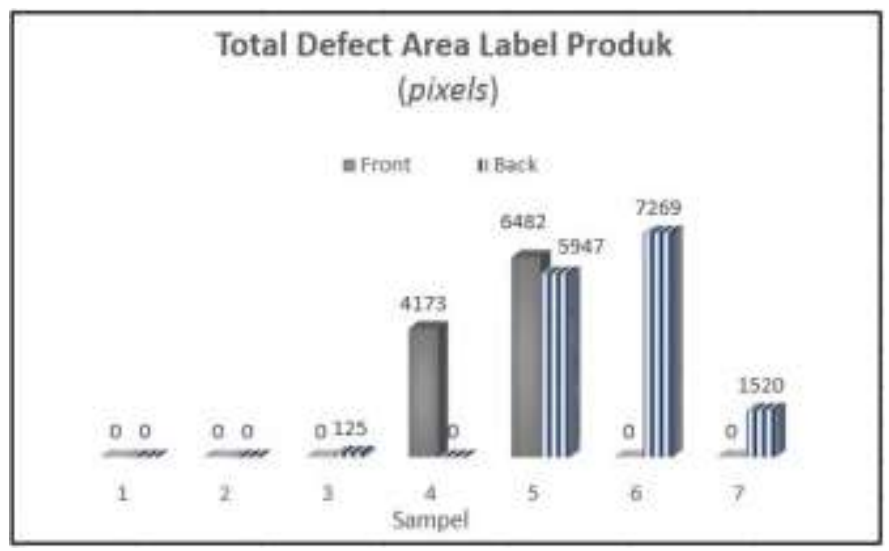

Gambar 10. Grafik total defect area pada label produk.

Grafik hasil total defect area diperoleh pada nilai masing-masing sampel pass dan fail pada label produk (Gambar 9). Nilai total defect area terbesar ditemukan pada sampel 6 di bagian front label yaitu 7269 pixels, dan total defect area dalam satu produk (label front dan back) terbesar diperoleh pada sampel No. 5 dengan penjumlahan total defect area front dan back adalah 12429 pixels.

Selama pengambilan data, iterasi saat inspeksi dalam satu sampel dilakukan guna mendapatkan tingkat kepresisian atau ketelitian data mengacu pada kedekatan kesepakatan antara hasil uji ISO 5725[9]. Dalam penelitian ini, uji presisi ditentukan dengan parameter RSD (Relatif Standard Deviasi) dari hasil deteksi total defect area pada semua sampel produk menggunakan formula 2-3[10]. Standar deviasi relatif (\%RSD) merepresentasikan ukuran ketelitian dari pengujian masing masing pengulangan pada sampel.

$\% R S D=\frac{S D}{P r} \times 100$

$\mathrm{SD}=\sqrt{\frac{\sum(P-P r)^{2}}{n-1}}$

keterangan;

$\mathrm{P}=$ nilai total defect area dari masing - masing percobaan
$\operatorname{Pr}=$ nilai rata - rata defect area

$\mathrm{n}=$ frekuensi penetapan

Hasil dari perhitungan \% RSD menunjukkan nilai 3,5\%. Semakin kecil nilai persentase RSD, maka semakin tinggi tingkat presisi. Jadi tingkat presisi dari sistem inspeksi yang telah dirancang untuk mendeteksi defect pada label memiliki tingkat kepresisian tinggi.

\section{KESIMPULAN}

Sistem inspeksi dengan pendekatan metode golden template comparison (GTC) dan konveyor pemilah telah berhasil digunakan untuk melakukan pengecekan defect pada dua sisi label di satu produk yang sama, yakni bagian depan dan bagian belakang label produk, dengan kemampuan tingkat ketelitian yang tinggi. Bagian mekanik konveyor dari sistem inspeksi ini mampu untuk menangkap dua sisi label pada produk untuk dilanjutkan pada proses deteksi cacat label produk dan memilah produk pass atau fail ditempatkan pada wadah sesuai hasil deteksi total defect area pada sisi masing-masing pelabelan. Produk dikategorikan pass jika kedua sisi label produk yaitu front dan back hasilnya adalah pass. Sedangkan produk dikategorikan fail jika salah satu sisi pada label adalah fail. Status pass dan fail ditentukan dengan jumlah total defect area yang mengacu pada standar klasifikasi cacat yang ditentukan. Selanjutnya, pengembangan dari penelitian ini dapat diintegrasikan dengan automatic system control berbasis IoT yang dapat diakses dan dipantau dari jarak jauh.

\section{REFERENSI}

[1] A. S. Nugroho, R. Umar, and A. Fadlil, "Sistem Pengenalan Botol Plastik Berdasarkan Label Merek Menggunakan Faster-RCNN," Nasional UMP, vol. 21, no. 2, pp. 111-118, 2020.

[2] N. Agani and T. H. Kusmanto, "Deteksi Label Komponen Pada Keping PCB Menggunakan Backpropagation Dan Self Organizing Map Neural Network," TELEMATIKA MKOM, vol. 6, no. 1, pp. 15-26, 2016.

[3] S. Padhee and D. J. T. d. S. Nandan, "Design of Automated Visual Inspection System for Beverage Industry Production Line," vol. 38, no. 2, pp. 461-466, 2021.

[4] B. Sugandi. and S. Dewi., "Sistem Inspeksi Kecacatan pada Kaleng Menggunakan Filter Warna HSL dan Template Matching," Khazanah Informatika, vol. 4 no. 2, 2018

[5] National Instrument, "NI Vision Builder for Automated Inspection Tutorial," https://www.ni.com/pdf/manuals/373379h.pdf, 2011.

[6] J. S. M. David, "Patent US-5640200-A," National Center for Biotechnology Information. PubChem vol. Accessed March 27, 2021.

[7] NI Vision Builder, Detect Defects Concept. Available from: https://documentation.help/NI-VisionBuilder/DetectDefects_Concepts.ht $\mathrm{ml}$.

[8] I. M. Doulah A, Farzana I. , "Improve the quality of products in woven apparel industries by plan-do-check-act (pdca) cycle.," J Innov Dev Strategy, no. 6(1), pp. 49-53, 2012.

[9] "ISO 5725-2:2019, Accuracy (trueness and precision) of measurement methods and results - Part 2: Basic method for the determination of repeatability and reproducibility of a standard measurement method," https://www.iso.org/standard/69419.html, Accessed March 22, 2021.

[10]Thesalonika Grinifh Arikalang, Sri Sudewi, and J. A. Rorong, "Optimasi dan Validasi Metode Analisis Dalam Penentuan Total Fenolik Pada Ekstrak Daun Gedi Hijau (Abelmoschus manihot L.) Yang Diukur Dengan Spektrofotometer Uv-Vis," Jurnal Ilmiah Farmasi, vol. 7 no. 3, 2018. 